received at the laboratory). Compared with direct immunofluorescence, near patient testing showed a sensitivity of $79 \%$ (95\% confidence interval $67.3 \%$ to $88.5 \%)$, a specificity of $97 \%(82.8 \%$ to $99.9 \%)$, a positive predictive value of $98 \%(89.6 \%$ to $99.9 \%)$, and a negative predictive value of $70 \%$ (53.9\% to $82.8 \%)$.

Near patient testing proved acceptable to the staff performing it, and it was well received in the hospital wards in terms of facilitating patient management and infection control.

\section{Comment}

The high specificity $(97 \%)$ of the enzyme immunoassay in this pilot confirmed results from a laboratory based study. ${ }^{3}$ The comparatively low sensitivity (79\%), although comparable with the sensitivity in another study, ${ }^{3}$ is partially explicable by our using a second, often smaller, specimen for the test. Our results suggest that a positive result of a near patient test is trustworthy and does not require laboratory confirmation (allowing considerable savings in both time and cost) but a negative result needs further investigation. Only one specimen per patient should routinely be required, but this should be treated aseptically to allow for possible laboratory referral.

Near patient testing for respiratory syncytial virus is a viable option for paediatric accident and emergency with important potential benefits.
Contributors: AM designed the study and oversaw the near patient testing. $\mathrm{NH}$ assisted in the study design, oversaw near patient and laboratory testing, and wrote the manuscript. EM oversaw and performed near patient testing. TB assisted in the study design and in writing the manuscript. Staff of the accident and emergency department, Royal Hospital for Sick Children, Edinburgh, and of the Regional Clinical Virology Laboratory, City Hospital, Edinburgh, provided technical help. Dr Peter Mackie (who has pioneered the concept of near patient testing for respiratory syncytial virus) and Pamela Joannidis (infection control nurse) at Yorkhill Children's Hospital, Glasgow, provided helpful advice. NH is guarantor for the paper.

Funding: Pump priming, Royal Hospital for Sick Children, Edinburgh.

Conflict of interest: None declared.

1 Wendt $\mathrm{CH}$, Hertz MI. Respiratory syncytial virus and parainfluenza virus infections in the immunocompromised host. Semin Respir Infect $1995 ; 10: 224-31$.

2 Langley JM, LeBlanc JC, Wang EEL, Law BJ, MacDonald NE, Mitchell I, et al. Nosocomial respiratory syncytial virus infection in Canadian pediatric hospitals: a Pediatric Investigators Collaborative Network on Infections in Canada study. Pediatncs 1997;100:943-6.

3 Todd SJ, Minnich L, Waner JL. Comparison of rapid immunofluorescence procedure with TestPack RSV and Directigen FLU-A for diagnosis of respiratory syncytial virus and influenza virus. J Clin Microbiol 1995;33:1650-1.

4 Woo PCY, Chiu SS, Seto W-H, Peiris M. Cost-effectiveness of rapid diagnosis of viral respiratory tract infections in paediatric patients. $J$ Clin Microbiol 1997;35:1579-81.

5 Joint Working Group on Quality Assurance. Guidelines on near to patient or point of care testing. Liverpool: Joint Working Group on Quality Assurance, 1999. (Available from Diagnostics Services, Mast House, Liverpool L20 1EA.)

(Accepted 5 March 1999)
National Addiction Centre, The

Maudsley Hospital and Institute of Psychiatry, London SE5 8AF

David Best, research coordinator

Alison Noble,

researcher

Emily Finch, consultant psychiatrist Michael Gossop head of research (addiction directorate

Clare Sidwell, researcher

John Strang

director

Correspondence to: D Best

d.best@iop.kcl.ac.uk

BMJ 1999;319:290-1
Infection with hepatitis $\mathrm{C}$ and hepatitis B viruses is common among injecting drug users. ${ }^{1-4}$ In a sample of blood donors only $0.01 \%$ were positive for antibodies to hepatitis $\mathrm{C}$ virus, ${ }^{5}$ whereas $59 \%$ of injecting drug users in East Anglia were positive, with $22 \%$ also positive for hepatitis B virus. ${ }^{2}$ Rhodes et al reported that about half (58\% in 1992 and 50\% in 1993) of those whose salivary specimens contained antibodies to hepatitis B virus were unaware of their infection. ${ }^{4}$ Although drug users are generally aware of the risks of infection, their awareness of their own status is uncertain. We tested opiate addicts receiving methadone maintenance treatment for markers of hepatitis B and hepatitis $\mathrm{C}$ infection and compared the results with their beliefs about their viral status.

\section{Subjects, methods, and results}

We collected data on 106 injecting opiate addicts attending a methadone maintenance clinic in London. Sufficient blood was obtained for 90 hepatitis C virus tests and for 84 hepatitis $\mathrm{B}$ virus tests (when blood was insufficient, priority was given to hepatitis $\mathrm{C}$ ). We present data for the 90 addicts from whom blood was obtained.

The participants' mean age was 36 years (range 21-54), and 69 were men. They had attended the clinic for an average of 2.4 years and received a mean methadone dose of $72 \mathrm{mg}$ (range 15-150 mg). Their mean age at first opiate injection was 21 , and the mean duration of injecting was 15 years. Fifty nine had used a syringe after someone else, and 68 had shared injecting paraphernalia.

Seventy seven were positive for hepatitis $\mathrm{C}$ virus, and 46 were positive for hepatitis $\mathrm{B}$ virus. Of the 79 who reported having previously been tested for hepatitis $\mathrm{C}$ virus, 58 thought they were positive, 16 thought they were negative (of whom half were wrong), and five were uncertain. Of the 70 addicts previously tested for hepatitis $\mathrm{C}$ virus whom we found to be positive, $12 \mathrm{did}$ not know or were wrong about their status (see table). Of the 41 previously tested for hepatitis B virus whom we found to be positive, 16 thought themselves to be negative.

Of the 11 addicts never previously tested for hepatitis $\mathrm{C}$ virus, four were correct in their self assessment (one positive, three negative), four incorrectly thought they were negative, and three did not know. Of the 22 addicts not previously tested for hepatitis B virus, six were correct in their self assessment (all negative), while three mistakenly believed they were positive and one negative, and 12 could not report their viral status (five positive, seven negative). 
Measured and reported status for infection with hepatitis B and hepatitis $C$ virus in opiate addicts receiving methadone maintenance treatment. Values are numbers of subjects

\begin{tabular}{|c|c|c|c|}
\hline \multirow[b]{2}{*}{ Actual status } & \multicolumn{3}{|c|}{ Perception of viral status } \\
\hline & Correct & Incorrect & Don't know \\
\hline \multicolumn{4}{|c|}{ Hepatitis C virus (seropositivity $86 \%(77 / 90)$ ) } \\
\hline \multicolumn{4}{|c|}{ Previously tested $(\mathrm{n}=79)$ : } \\
\hline Positive & 58 & 8 & 4 \\
\hline Negative & 8 & 0 & 1 \\
\hline \multicolumn{4}{|c|}{ Not previously tested $(\mathrm{n}=11)$ : } \\
\hline Positive & 1 & 4 & 2 \\
\hline Negative & 3 & 0 & 1 \\
\hline \multicolumn{4}{|c|}{ Total group $(n=90)$ : } \\
\hline Positive & 59 & 12 & 6 \\
\hline Negative & 11 & 0 & 2 \\
\hline \multicolumn{4}{|c|}{ Hepatitis B virus (seropositivity 55\% (46/84)) } \\
\hline \multicolumn{4}{|c|}{ Previously tested $(n=62)$ : } \\
\hline Positive & 25 & 16 & 0 \\
\hline Negative & 18 & 2 & 1 \\
\hline \multicolumn{4}{|c|}{ Not previously tested $(\mathrm{n}=22)$ : } \\
\hline Positive & 0 & 1 & 5 \\
\hline Negative & 6 & 3 & 7 \\
\hline \multicolumn{4}{|c|}{ Total group $(n=84)$ : } \\
\hline Positive & 25 & 17 & 5 \\
\hline Negative & 24 & 5 & 8 \\
\hline
\end{tabular}

Subjects never previously tested for hepatitis B virus were less likely to be seropositive $(5 / 22 v 41 / 62$; $\left.\chi^{2}=10.66, \mathrm{df}=1, \mathrm{P}<0.005\right)$. A similar pattern was seen for hepatitis $\mathrm{C}$ virus positivity $\left(7 / 11 v 70 / 79 ; \chi^{2}=3.06\right.$, $\mathrm{df}=1, \mathrm{P}<0.10)$. Of the 33 addicts not previously tested for hepatitis $\mathrm{B}$ or hepatitis $\mathrm{C}$ virus, only 10 accurately perceived their combined status.

\section{Discussion}

Our finding of $86 \%$ seropositivity for hepatitis $\mathrm{C}$ virus is consistent with the $67 \%$ found among Australian injecting drug users ${ }^{1}$ and $75 \%$ among UK addicts receiving maintenance treatment. ${ }^{3}$ The participants' perceptions of their viral status were often inaccurate: for both hepatitis B and hepatitis C virus, they tended to believe they were negative when they were positive. If untested drug users assume they are positive and act accordingly they pose no threat to public health. If they mistakenly presume negative status, this may have serious public health consequences. Clinicians should encourage testing in all patients who are injecting drug users and use this as a catalyst for interventions. As Crofts et al point out, ${ }^{1}$ drug treatment alone is not sufficient in reducing hepatitis seroconversion and clinicians must be more vigorous in encouraging drug users to reduce risk behaviours.

\section{We thank the staff and patients involved in the study.}

Contributors: JS, DB, and EF conceived and initiated the study, for which the data were then collected by DB, EF, AN, and CS. All authors contributed to the analysis and preparation of the article. DB, EF, and JS are guarantors for the study.

Funding: No specific funding. All the authors are employees of the Institute of Psychiatry or Bethlem and Maudsley NHS Trust. Their research work is also supported by the charity Action on Addiction.

Competing interests: None declared.

1 Crofts N, Nigro L, Oman K, Stevenson E, Sherman J. Methadone maintenance and hepatitis $\mathrm{C}$ virus infection among injecting drug users. Addiction 1997;92:999-1005.

2 Majid A, Holmes R, Desselberger U, Simmonds P, McKee TA. Molecular epidemiology of hepatitis $\mathrm{C}$ virus infection among intravenous drug users in rural communities. J Med Virol 1995;46:48-51.

3 Serfaty MA, Lawrie A, Smith B, Brind AM, Watson JP, Gilvarry E, et al. Risk factors and medical follow-up of drug users tested for hepatitis C-can the risk of transmission be reduced? Drug Alcohol Rev 1997;16:339-47.

4 Rhodes T, Hunter GM, Stimson GV, Donoghoe MC, Noble A, Parry J, et al. Prevalence of markers for hepatitis B virus and HIV-1 among drug injectors in London: injecting careers, positivity and risk behaviour. Addiction 1996;91:1457-67.

5 Dow BC, Coote I, Munro H, McOmish F, Yap L, Simmonds P, et al. Confirmation of hepatitis $\mathrm{C}$ antibody in blood donors. J Med Virol 1997;41:215-20.

(Accepted 18 February 1999)

\title{
Effect of mass media campaign to reduce socioeconomic differences in women's awareness and behaviour concerning use of folic acid: cross sectional study
}

\author{
H E K de Walle, K M van der Pal, L T W de Jong-van den Berg, W Jeeninga, J S A G Schouten, \\ C M de Rover, S E Buitendijk, M C Cornel
}

In September 1995, a mass media campaign on the use of folic acid to reduce the risk of fetal neural tube defects started in the Netherlands. ${ }^{1}$ Special emphasis was placed on reaching women in low socioeconomic categories. We describe the effect of the campaign on awareness and use of folic acid in relation to socioeconomic status.

\section{Subjects, methods, and results}

We measured the effect of the campaign by comparing two cross sectional studies-one conducted before the campaign and one conducted after the campaign. We asked pregnant women in four regions of the Nether- lands attending their first or second antenatal visit to fill out a questionnaire; all did so.

We took highest fulfilled education, a recognised indicator of socioeconomic status, and merged it into three levels: low, middle, and high. We used multivariate logistic regression to calculate adjusted odds ratios for high versus low education. The methodology has been described elsewhere. ${ }^{2}$

In both studies, $90 \%$ of the pregnancies were planned. After the campaign, 89.1\% (1437/1612) of the respondents had heard about folic acid and $76.9 \%$ (1240) had heard about it before their pregnancy; the table shows how this is related to level of education. 